\title{
Identifikasi Penderita Hipertensi untuk Melakukan Pengobatan Secara Teratur Melalui Konseling di Kota Padang
}

\author{
Sri Siswati ${ }^{*}$ \\ ${ }^{1}$ Program Studi IKM Fakultas Kesehatan Masyarakat, Universitas Andalas \\ "e-mail: srisiswati@yahoo.co.id
}

\begin{abstract}
Abstrak- Penyakit merupakan uncertainty atau sesuatu yang tidak pasti kapan datangnya, karena itu pelayanan kesehatan masyarakat Penyakit Tidak Menular (PTM) perlu dicegah. Penelitian ini deskriptif observasi. PTM yang diperiksa di daerah Gunung Padang Sumatera Barat. Penelitian yang bertujuan untuk 1) menyajikan factor resiko PTM kesehatan masyarakat yang akan berolahraga pagi di daerah Gunung Padang. 2) mengukur faktor resiko yang dialami masyarakat dalam PTM 3) Memberikan konseling kesehatan masyarakat Prosedur penelitian dengan melaksanakan cek faktor resiko kesehatan masyarakat, menganalisis pencapaian keluarga sehat dari beberapa sumber serta memberikan solusi kepada mesyarakat dengan menggunakan peralatan digital yang bisa digunakan. Hasil menunjukkan faktor resiko yang paling tinggi penyakit hipertensi, Konseling kepada masrakat untuk selalu melaksnakan cek kesehatan, enyahkan asap rokok, rajin aktifitas fisik, diet berimbang, istirahat yang cukup serta kendalikan stres. Analisis menunjukkan pendekatan keluarga dapat mencegah faktor resiko terhadap PTM, karena paling dekat dengan masyarakat Oleh karena itu dapat disimpulkan bahwa model pendekatan keluarga dimanapun berada dapat mencegah faktor resiko terhadap PTM.
\end{abstract}

Kata Kunci : Penyakit Tidak Menular (PTM), Hipertensi, Konseling, Pendekatan Keluarga

\begin{abstract}
Disease is an uncertainty or something that is uncertain when it comes, therefore public health services Non-Communicable Diseases (PTMs need to be prevented. This study presents descriptive PTMs examined in the Gunung Padang West Sumatera area. Research aimed at 1) presents PTM risk factors public health who will exercise early in the morning at Bukit Gado-Gado. 2) to measure the risk factors experienced by the community in PTM 3) Providing public health counseling The research procedure was carried out by looking at a picture of community health risk factors, analyzing the achievement of healthy families from several sources and providing solutions to the community by using digital equipment regularly The results show the highest risk factor for hypertension. Counseling to the community to always carry out health checks, get rid of cigarette smoke, diligent physical activity, balanced diet, adequate rest and control of stress. Analysis shows that the family approach can prevent risk factors for Non-Communicable Disease (NCD), because it is closest to the community. Therefore, it can be concluded that the family approach model wherever located can prevent risk factors for NCD.
\end{abstract}

Keywords : Non-Communicable Diseases (NCD), Hypertension, Counseling, Family Approach 


\section{Pendahuluan}

Penyakit merupakann unsertainty atau sesuatu yang tidak pasti kapan datangnya, karena itu perlu pelayanan kesehatan yang menjaminnya. UndangUndang Kesehatan Nomor 36 tahun 2009 menyatakan "Setiap orang mempunyai hak dalam memperoleh pelayanan Kesehatan yang aman, bermutu, dan terjangkau" [1]. Sehingga, derajat Kesehatan perorangan maupun keluarga atau masyarakat dapat meningkat.

Pelayanan kesehatan masuk ke ranah tiga pilar Program Indonesia Sehat (PIS), yang mempunyai sasaran semua umur dengan mengikuti siklus kehidupan atau life cycle. Pemberian pelayanan kesehatan akan lebih efektif melalui "pendekatan keluarga". Penyakit mulai bergeser dari penyakit menular kearah Penyakit Tidak Menular. Pusat Data Indonesia menunjukkan sebagian besar "hipertensi" 23,76. [2]

Sesuai dengan panduan pelaksanaan Program Indonesia Sehat dan merujuk pada Permenkes Nomor 39 tahun 2017 tentang Program Indonesia Sehat dengan "Pendekatan Keluarga" (PIS-PK) menjelaskan bahwa: (1) perlunya meningkatkan peranan dan kepedulian keluarga terhadap peningkatan pelayanan Kesehatan yang menyeluruh, yang meliputi pelayanan "promotif: dan pencegahan serta pelayanan "pengobatan dan pemulihan"; (2) dukungan ketercapaian standar pelayanan minimal kabupaten/kota melalui meningkatnya akses dan cek kesehatan; (3) peningkatan kesadaran masyarakat untuk menjadi peserta Jaminan Kesehatan Nasional; melalui dukungan pelaksanaan jaminan kesehatan nasional (4) Meningkatkan peran keluarga dalam pencapaian tujuan Program Indonesia Sehat dan renstra Kementerian Kesehatan Tahun 2015-2019 yang baru berlalu. [3][4][5]

Kementrian Kesehatan biasanya mengadakan Riset Kesehatan Dasar (Riskesdas) setiap 5 tahun. Hasil Riskesdas Penyakit tidak menular (PTM) meningkat tajam dari tahun 2013 ke 2018. Penyakit Tidak Menular antara lain kanker 1,4\% pada tahun 2013 meninkat 1,8\% pada tahun 2018. Ginjal Kronik 2\% menjadi 3,8\% tahun 2018, Hipertensi atau tekanan darah tinggi $25,8 \%$ menjadi $34,1 \%$ pada tahun 2018 yang diukur pada penduduk umur >sama 8 tahun, Diabetes militus dari 6,9\% tahun 2013 meningkat 8,5\% pada tahun 2018. [6]

Penyakit Stroke 7\% pada tahun 2013 menjadi $10,9 \%$ pada tahun 2018. Penyakit jantung terdeteksi tahun 2018 1,5\% Gaya hidup sehat masyarakat berpengaruh timbulnya factor resiko penyakit tidak menular tersebut. Data kenaikan hasil Riskesdas di atas menunjukkan hipertensi yang paling tinggi.

Mencegah factor resiko Penyakit Tidak Menular dengan merubah perilaku dan gaya hidup masyarakat yang dikenal dalam istilah CERDIK. Cek Kesehatan secara berkala, Enyahkan asap rokok, Rajin Aktifitas Fisik, Diet Berimbang, Istirahat yang cukup dan Kendalikan Stress.

Menurut data Profil Kesehatan Kota Padang tahun 2018 dari 150.591 jiwa penduduk umur diatas atau sama 15 tahun yang dilakukan pengukuran tekanan darah, terdapat 108.104 orang yang dilayani dengan diagnose hipertensi sebesar $4,64 \%$. Penderita yang diperiksa terbanyak adalah perempuan yaitu 60.283 orang dan laki-laki sebanyak 47.821 orang.

Adapun yang dimaksud dengan Penyakit Tidak Menular (PTM) adalah penyakit yang tidak ditularkan dari orang ke orang, Perkembangan penyakit ini berjalan perlahan dalam jangka waktu yang panjang (kronis). Penyebab utamanya adalah perilaku dan lingkungan yang tidak sehat, dimana 7 dari 10 orang tidak mengetahui / menyadari dirinya terkena PTM [7]. Penyakit ini merupakan pembunuh terbesar di dunia. dimana lebih kurang 35 juta kematian setiap tahunnya atau sekitar $60 \%$ seluruh kematian tejadi karena jantung, stroke, tekanan darah tinggi, diabetes mellitus, kanker, penyakit paru obstruktif serta kejadian cedera.

Tekanan darah tinggi merupakan "silent killer" individu dan gejalanya hampir sama dengan gejala penyakit lainnya. Oleh karena itu, masih banyak orang yang tidak menyadari terkena hipertensi, sehingga, penting untuk mengukur tekanan darah secara rutin dan teratur [8]. Tekanan darah tinggi dapat terdeteksi melalui pemeriksaan tekanan darah dengan rutin dan teratur. Biasanya gejala tekanan darah tinggi atau tekanan darah tinggi ditandai dengan sakit kepala atau berat di tengkuk, vertigo, jantung berdebar-debar, nyeri dada, kelelahan, kecemasan, penglihatan kabur,telinga berdenging (tinitus), dan keluar darah dari hidung [8][9].

Program Indonesia Sehat melalui Pendekatan Keluarga memiliki 12 indikator utama yang dapat dijadikan sebagai penanda status kesehatan sebuah keluarga. Ke 12 indikator tersebut terdapat dalam 5 kelompok utama, yang terdiri dari: 5 indikator dalam gizi (1) Keluarga mengikuti program KB;(2) Ibu melakukan persalinan di fasilitas kesehatan; (3) bayi mendapat imunisasi dasar lengkap; (4) Bayi mendapat Air Susu Ibu (ASI) eksklusif; (5) Balita mendapatkan pemantauan pertumbuhan; 2 Indikator pengendalian penyakit tidak menular : (6) Penderita tuberculosis paru mendapatkan 
pengobatan sesuai standar; (7) Penderita hipertensi melakukan pengobatan secara teratur; Satu indicator kesehatan jiwa (8) Penderita gangguan jiwa mendapatkan pengobatan dan tidak ditelantarkan; Dua Indikator dalam Perilaku Dehat (9) Anggota keluarga tidak ada yang merokok;(10) keluarga sudah menjadi anggota Jaminan Kesehatan Nasional; Dua indikator terkait lingkungan sehat (11) Keluarga mempunyai akses sarana air bersih; (12) menggunakan akses jamban keluarga. Untuk pembinaan Penyakit Tidak Menular ini di kota Padang dilakukan oleh puskesmas-puskesmas dan Pos Pembinaan Terpadu (Posyandu) [10].

Menurut data Pusat Data dan Informasi Kementerian Kesehatan Republik Indonesia tahun 2018, memuat data pencapaian cakupan indikator keluarga sehat di Indonesia. Data tersebut menunjukkan bahwa penderita tekanan darah tinggi yang berobat secara teratur merupakan salah satu indikator keluarga sehat dengan cakupan terendah secara nasional.

Peningkatan kematian akibat Penyakit Tidak Menular (PTM) ini menjadi ancaman serius dalam kesehatan masyarakat, karena akan menambah beban social ekonomi keluarga maupun masyarakat. Dari setiap 100 orang penyandang PTM, terdapat 70 orang tidak menyadari dirinya sedang mengidap PTM, sehingga dapat menyebabkan terlambat mendapatkan penanganan yang bisa mengakibatkan terjadinya komplikasi. Sebetulnya untuk mengetahui faktor reriko Penyakit Tidak Menular melalui pengukuran tekanan darah, gula darah sewaktu, dan Indeks Masa Tubuh (IMT) dapat dilakukan secara mandiri, disamping dilakukan melalui bantuan Puskesmas maupun Posyandu.

Menurut data dari Program Indonesia Sehat dengan Pendekatan Keluarga (PIS-PK) serta hasil Riset Kesehatan Dasar 2018[11], dan meningkatnya penyakit tidak menular, peneliti meneliti dengan mencek kesehatan masyarakat yang sedang melakukan aktifitas fisik di Bukit Gado-Gado Gunung Padang bekerja sama dengan Puskesmas Pemancungan.

Tujuan penelitian ini adalah (1) untuk melihat kecendrungan faktor resiko penyakit tidak menular pada masyarakat yang sudah melaksanakan aktifitas fisik, (2) kecendrungan faktor resiko dominan yang dialami masyarakat, (3) memberikan solusi bagi masyarakat dalam mengatasi faktor resiko yang dialami serta (4) memberikan konseling kepada masyarakat untuk mengantisipasi penyakit tidak menular yang dideritanya serta bagaimana mengatasinya.
Salah satu upaya dalam mengatasi penderita tekanan darah tinggi adalah melakukan pengobatan secara teratur. Konseling dibutuhkan oleh pasien dapat diberikan oleh petugas kesehatan. Pemberian konseling dapat dengan cara pembentukan tim yang terdiri dari petugas kesehatan, staf nagari, serta kader kesehatan untuk memberikan edukasi kepada masyarakat tentang pentingnya melakukan pengobatan secara teratur. Penderita atau yang mempunyai faktor resiko penyakit dapat dilatih dangan sarana digital untuk mengetahuinya. Ingin diketahui bagaimana factor resiko penyakit tidak menular di daerah Gunung Padang yang merupakan tempat masyarakat berolahraga dan apakah dari hasil konseling masyarakat mengetahui bagaimana penanganan dan pencegahannya.

\section{METODA}

Penelitian deksrptif observasional dengan pendekatan pendeteksian faktor resiko penyakit tidak menular pada masyarakat yang sering melakukan aktifitas fisik. Responden secara random sampling melakukan cek Kesehatan sebelum aktifitas fisik. Cek kesehatan masyarakat dilaksanakan untuk melihat faktor resiko pada populasi yang sering melakukan aktifitas fisik. Kegiatan pemeriksaan dibatasi pada faktor resiko penyakit Kegemukan, Diabetes, Glukosa Darah sewaktu dan Pengukuran Tekanan Darah. Kegiatan faktor resiko penyakit tidak menular ini diakhiri dengan konseling terhadap perilaku untuk menghindari.

Penelitian dengan pendeteksian faktor resiko penyakit tidak menular (MTM) pada masyarakat yang sering melakukan aktifitas fisik dengan melakukan cek kesehatan pada saat melakukan aktifitas fisik. Cek kesehatan masyarakat dilaksanakan untuk melihat faktor resiko pada populasi yang sering melakukan aktifitas fisik. Kegiatan pemeriksaan dibatasi pada faktor resiko penyakit Kegemukan, Diabetes, Glukosa Darah sewaktu dan Pengukuran Tekanan Darah. Kegiatan factor resiko penyakit tidak menular ini diakhiri dengan konseling terhadap perilaku untuk menghindari terjangkitnya PTM.

Secara umum tujuan dari Pengecekan kesehatan masyarakat adalah mengidentifikasi permasalahan kesehatan masyarakat, khusunya untuk factor resiko. Penyakit Tidak Menular (PTM). Ada beberapa pendekatan dalam mewujudkan Indonesia Sehat melalui kegiatan yaitu pertama istilah CERDIK (Cek Kesehatan, Enyahkan Asap rokok, Rajin aktifitas fisik, Diet berimbang, 
Istirahat yang cukup, Kendalikan stress. Kedua yang sering dilakukan puskesmas adalah (PIS-PK), yaitu peningkatan Penyelenggaraan Indonesia Sehat melalui Pendekatan Keluarga melalui pengajuan pembentukan Tim Gerak Cepat (TGC). Penyakit yang dominan Hipertensi, menggunakan peralatan pengukuran dengan berbasis digital.

Program Pencegahan Faktor Resiko Penyakit Tidak Menular ini dilaksanakan biasanya melalui Pobindu atau Pos Pembinaan Terpadu dengan tenaga yang dilatih oleh Dinas Kesehatan Provinsi Sumatera Barat. Penelitian ini mengidentifikasi masalah kesehatan masyarakat di wilayah Gunung Padang Padang yang merupakan wilayah kerja Puskesmas Pemancungan. Ke depan program Identifikasi Faktor Resiko Penyakit Tidak Menular ini diadakan di setiap instansi seperti Organisasi Perangkat Daerah, Kampus-kampus, Pasar, dan lain sebagainya. Peneliti mencoba pedoman ini di daerah Gunung Padang untuk menyarakat yang akan menjalankan aktifitas fisiknya melalui jalan pagi. Penelitian ini merupakan manajemen dalam Ilmu Kesehatan Masyarakat [12][13]

\section{HASIL DAN PEMBAHASAN}

\section{A. Hasil}

Wilayah identifikasi terletak di Gunung Padang yang terkenal dengan pemandangan lautnya yang sangat indah. Dari Jalam Muaro ke jembatan Siti Nurbaya adalah jalur untuk mancapai Pantai Air Manis yang terkenal dengan Patung Malin Kundangnya. Selain tempat wisata, wilayah ini dimanfaatkan warga kota Padang untuk beraktifitas fisik setiap hari sabtu dan minggu. Warga Padang mudah untuk menemukannya. Seiring dengan usaha pemerintah Sumatera Barat untuk mengembang-kan wilayah pariwisata di Sumatera Barat, pemerintah kota Padang juga giat membangun dan mengembang-kan lokasi wisata. Salah satunya adalah membangun jalan dari Muara Padang, Bukit Gado gado menuju Pantai Air Manis melewati Gunung Padang.

Banyak warga saat ini yang memanfaatkan jalan di sepanjang bukit ini untuk olah raga fisik di pagi hari. Sedangkan sore hari mereka tumpah ruah ke punggung bukit untuk menikmati sunset. Gunung Padang mempunyai jalanan berupa turunan dan tanjakan layaknya konstruksi perbukitan namun tidak terlalu terjal. Bukit Gadogado banyak masyarakat yang lari atau jalan di pagi hari, namun tidak dilakukannya pemeriksaan kesehatan. Peningkatan Kesehatan masyarakat sangat dibutuhkan. Masyarakat yang tidak melakukan pemeriksaan kesehatan biasanya mempunyai alasan seperti tidak punya biaya, merasa dirinya sehat-sehat saja atau karena malas untuk pergi ke dokter. Disamping itu banyak juga yang pergi berobat atau memeriksa kesehatan setelah mulai merasakan adanya gejala penyakit tersebut, padahal itu sudah terlambat. Permasalahan yang muncul, masyarakat yang beraktifitas fisik di Bukit Gado-gado adalah tidak di cek Kesehatan sebelum mereka melakukan olah raga. Seiring dengan beralihnya peningkatan Penyakit Tidak Menular disamping masalah penyakit menular, dilaksanakan mengukuran kesehatan masyarakat di wilayah ini. Jumlah peserta yang diperiksa sejumlah 55 orang dengan hasil menunjukkan factor resiko untuk penyakit tidak menular.

\section{a. Jenis Kelamin (JK)}

Berdasarkan jenis kelamin masyarakat yang di cek kesehatannnya dijelaskan pada tabel 1 .

Tabel 1. Jenis Kelamin

\begin{tabular}{|l|r|c|}
\hline $\begin{array}{c}\text { Jenis } \\
\text { Kelamin }\end{array}$ & $\begin{array}{c}\text { Freku } \\
\text { enci }\end{array}$ & Persent \\
\hline Laki-Laki & 41 & 74.5 \\
\hline Perempuan & 14 & 25.5 \\
\hline Total & 55 & 100 \\
\hline
\end{tabular}

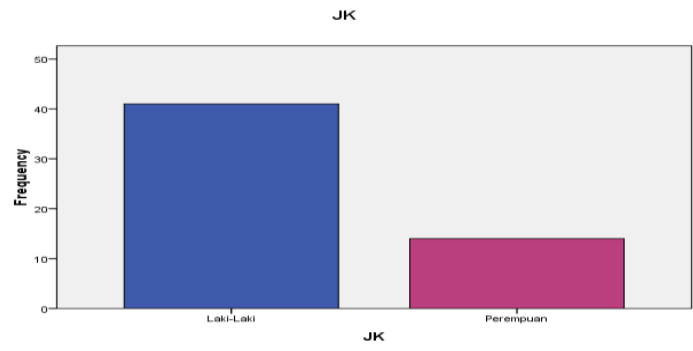

Gambar 1. Jenis Kelamin Responden

Pemeriksaan faktor resiko penyakit tidak menular dilakukan dengan komposisi responden laki-laki sebanyak 41 orang dan perempuan sebanyak 14 orang. Perbandingan jenis kelamin dapat dilihat pada gambar 1.

\section{b. Indeks Masa Tubuh (IMT)}

Pengukuran indeks masa tubuh dicari dengan rumus Berat Badan dibagi dengan Tinggi badan kuadrat. Seseorang dikatakan obesitas jika telah memiliki Indeks Masa Tubuh lebih dari $25 \mathrm{~kg} / \mathrm{m}^{2}$. Obesitas ini juga memicu terjadinya faktor resiko penyakit tidak menular seseorang. Perbandingan berat badan dengan tinggi badan harus seimbang atau normal. 
Hasil pengukuran Indeks Masa Tubuh masyarakat yang diperiksa dapat dilihat pada tabel dibawah ini. (IMT).

Tabel 2. Indeks Masa Tubuh

\begin{tabular}{|l|c|c|}
\hline & Frekuensi & Percen \\
\hline Normal & 27 & 49.1 \\
\hline Gemuk & 27 & 49.1 \\
\hline Total & 54 & 98.2 \\
\hline System & 1 & 1.8 \\
\hline
\end{tabular}

KATEGORI_IMT

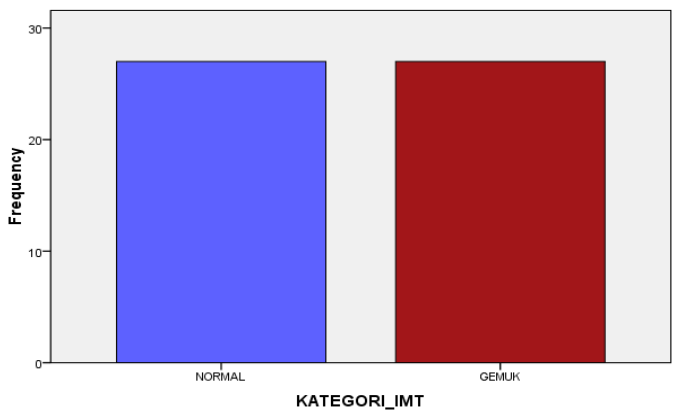

Gambar 2. Indeks Masa Tubuh

Dari data pada tabel 2 dan gambar 2 dapat dilihat bahwa kecendrungan IMT yang melewati batas normal ada $49,1 \%$. Masyarakat dengan IMT normal ada 49,1\% atau sama dengan kecendrungan gemuk. Masyarakat yang gemuk diupayakan untuk hati-hati terhadap factor resiko terkena penyakit tidak menular.

\section{c. Pengukuran Tekanan Darah}

Pengukuran tekanan darah responden yang dilakukan terlihat pada tabel 3 .

Tabel 3. Tekanan Darah Responden

\begin{tabular}{|l|c|c|}
\hline $\begin{array}{c}\text { Kondisi } \\
\text { Tekanan Darah }\end{array}$ & Frekuensi & $\begin{array}{c}\text { Percen } \\
(\%)\end{array}$ \\
\hline Normal & 22 & 40 \\
\hline $\begin{array}{l}\text { Pretekanan } \\
\text { darah tinggi }\end{array}$ & 27 & 49,1 \\
\hline $\begin{array}{l}\text { Tekanan } \\
\text { Darah Tinggi }\end{array}$ & 6 & 10,9 \\
\hline Total & 55 & 100 \\
\hline
\end{tabular}

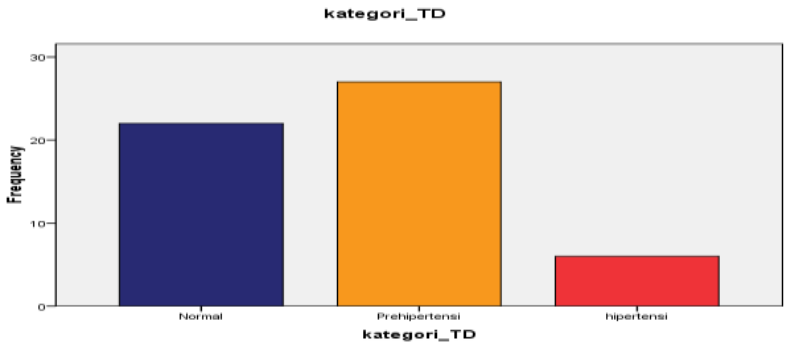

Gambar 3. Proporsi Tekanan Darah
Dapat kita lihat bahwa hanya 6 responden yang tekanan darahnya tergolong hipertensi Sisanya sebagian besar mempunyai potensi untuk tekanan darah tinggi yaitu 27 orang. Jumlah yang telah dan punya resiko tekanan darah tinggi 33 orang responden adalah $60 \%$. Cukut tinggi, sebelum mereka melaksanakan aktifitas

Tabel 4. Pengukuran Gula Darah

\begin{tabular}{|l|c|c|}
\hline \multicolumn{1}{|c|}{ Status } & Frekuensi & Percent \\
\hline Normal & 49 & 89.1 \\
\hline Prediabetes & 3 & 5.5 \\
\hline Diabetes & 2 & 3.6 \\
\hline Total & 54 & 98.2 \\
\hline System & 1 & 1.8 \\
\hline
\end{tabular}

\section{B. Pembahasan}

Peningkatan kematian akibat Penyakit Tidak Menular (PTM) ini sudah menjadi ancaman serius bagi Kesehatan masyarakat, karena akan menambah beban sosial ekonomi keluarga. Dari setiap 100 orang penyandang PTM terdapat sebanyak 70 orang tidak menyadari dirinya mengidap PTM, sehingga terlambat dalam mendapat penanganan yang mengakibatkan terjadinya komplikasi. Skrining faktor risiko PTM seperti pengukuran Indeks Masa Tubuh, Tekanan Darah dan Gula Darah dan lain-lain sebenarnya dapat dilakukan secara mandiri oleh setiap orang, tetapi banyak yang memerlukan bantuan melalui sarana pelayanan kesehatan seperti puskesmas, Pos Pembinaan Terpadu (Posbindu). Dari pengukuran faktor resiko dan telah terjadinya Penyaki Tidak Menular di wilayah bukit Gado-gado ini yang paling tinggi adalah Hipertensi sebesar 60 persen. Berat badan ideal hanya dimiliki oleh 50 persen responden. Glukosa darah untuk factor resiko terjadinya diabetes tidak terlihat. Sebanyak 89,1 persent responden memiliki kadar gula darah yang ideal dan prediabetes hanya $5,5 \%$. Berat badan yang menunjukkan faktor resiko kegemukan sebanyak hamper 50 persen harus dikontrol untuk menjadi ideal. Sebagian besar responden adalah masyarakat yang setiap minggu berolah raga fisik secara teratur.

Tekanan darah tinggi adalah gejala dimana tekanan darah systole melebihi $120 \mathrm{mmHg}$ dan atau tekanan diastole melebihi $80 \mathrm{mmHg}$. Beberapa sumber keadaan normal menyebut $140 \mathrm{mmHg}$ dan diastole melebihi 90mmHg. Supaya aman, biasanya lebih banyak yang mengambil sumber $120 \mathrm{mmHg}$ untuk sistole dan $80 \mathrm{mmHg}$ untuk diastole (WHO, Kepmenkes 2018). [14] 
Ciri dan keadaan tekanan darah tinggi yang perlu diwaspadai adalah sakit kepala, kelelahan, mual dan muntah, sesak nafas, nafas pendek, tidak tenang. Gejala lain pandangan menjadi kurang jelas, mata berkunang-kunang, mudah marah, telinga berdengung, susah untuk tidur dan rasa yang tidak nyaman di tengkuk. Pada tahap intervensi dilakukan konseling dalam penanganan faktor resiko dan resiko sesudah mengalami tekanan darah tinggi.

Dari beberapa cara mencegah resiko untuk menghadapi tekanan darah tinggi adalah melakukan konseling. Dari hasil konseling kita bisa menganalisis Riwayat responden mulai dari merokok, kebiasaan hidup, tidak makan buah dan sayur, tidak istirahat dengan cukup serta tidak mampu mengendalikan stress.

Hasil penelitian ini jika dibandingkan dengan penelitian Feranita Utama [15] di Universitas Sriwijaya memperlihatkan bahwa masyarakat yang menderita tekanan darah tinggi sebesar $27,3 \%$ dan mengalami obesitas sebesar $34,5 \%$ menunjukkan kesamaan. Angka tingginya kecendrungan hipertensi menunjukkan juga IMT yang tidak normal atau kegemukan. Kasus hipertensi dan kegemukan pada pegawai Universitas Sriwijaya termasuk tinggi. Penelitian Adhania tentang prevalensi pada tahun 2013, 2015, dan 2017 menunjukkan prevalensi PTM di Kota Bandung secara berurutan yaitu $25,35 \%, 23,21 \%$, dan $26,98 \%$ [16].

Hasil konseling terhadap responden yang diperiksa hampir $90 \%$ tidak mengenal pengukuran lingkar pinggang yang melebihi batas normal lebih $90 \mathrm{~cm}$ untuk kaum laki-laki dan melebihi $80 \mathrm{~cm}$ untuk kaum perempuan tidak normal dan rentan untuk terjadinya faktor resiko. Demikian juga pengukuran IMT tidak dikenal masyarakat batas normalnya. Padahal ini bisa dilakukan oleh keluarga yang bersangkutan atau dengan bantuan tenaga Kesehatan atau kader kesehatan. Pemeriksaan kadar gula darah responden yang sudah menderita diabetes memahami batas normal darah, tetapi yang mempunyai faktor resiko tidak mengetahuinya.

Nurul Ilmi Idrus [17] dalam penelitiannya mendapatkan ada hubungan bermakna variable tingkat pendidikan, akses pelayanan Kesehatan dan dukungan keluarga dengan pemeriksaan rutin tekanan darah, sedangkan variable jenis pekerjaan tidak berhubungan dengan pemeriksaan rutin tekanan darah pada pasien tekanan darah tinggi. Disarankan kepada masyarakat agar selalu mengikuti sosialisasi yang berhubungan dengan hipertensi untuk meningkatkan pengetahuan bagi para penderita tekanan darah tinggi. Petugas kesehatan secara intensif sebaiknya memberikan penyuluhan yang kepada masyarakat mengenai perlunya melakukan control tekanan darah secara rutin untuk menghindari komplikasi.

Hasil penelitian Hasanudin [18] di wilayah Tlugosuryo Kota Malang dalam penelitiannya menemukan terdapatnya hubungan aktifitas fisik dengan tekanan darah pada masyarakat penderita tekanan darah tinggi. Perlu masyarakat melakukan berolahraga atau aktifitas fisik secara rutin sehingga dapat menstabilkan tekanan darahnya. $81,39 \%$ masyarakat yang beraktifitas fisik tekanan darahnya berada pada stadium 1, masih dikatagorikan normal dan aman.

Untuk cek kesehatan setiap saat, responden atau masyarakat dijelaskan dapat menggunakan alat berbasis digital yang bisa dilakukan sendiri atau bantuan pihak keluarga. Yang dijelaskan kepada masyarakat bagaimana mereka melakukan dengan benar, dan melihat alat yang digunakan tidak kadaluarsa. Pengukuran ini juga terbatas cek Kesehatan yang direkomendasikan. Apabila ada kendala responden atau meragukan, dianjurkan melakukan dan mengkonsultasikan pada pelayanan kesehatan, pada pos pelayanan terpadu (Posbindu) yang dibina puskesmas [19].

Hasil konseling terhadap responden sejalan dengan penelitian Siswati, Shafira at all 2019 di wilayah puskesmas Paninjauan Kabupaten Solok yang merupakan Inovasi Kegiatan Pencegahan tekanan darah tinggi dengan pembentukan Tim Gerak Cepat mencegah faktor Resiko Tekanan Darah Tinggi [19][20]. Tahapnya dijelaskan pada penjabaran di bawah ini :

a. Mengadakan penyuluhandengan sasaran Tim Gerak Cepat (TGC) Tekanan darah tinggi dan tokoh masyarakat Nagari Labuah Panjang dengan materi yang berkaitan dengan tekanan darah dan bahayanya. Hasil intervensi dari sebelumnya adalah meningkatnya pengetahuan Tim pelaksana Tim Gerak Cepat Hipertensi. Indikator yang ditetapkan adalah Terlaksananya penyuluhan bahaya peningkatan tekanan darah.

b. Pembentukan Tim Gerak Cepat (TGC) hipertensi dari tidak ada menjadi ada.

c. Penyebaran Leaflet

d. Pemasangan stiker "KADARSI" (keluarga sadar hipertensi)

Kegiatan ini sangat direspon baik oleh pihak puskesmas, tokoh masyarakat dan masyarakat yang merasakan dampaknya. Mengatasi factor resiko Penyakit Tidak Menular ini belum banyak dilakukan di kampus-kampus, khususnya di 
Sumatera Barat. Promosi tentang hidup sehat ada dilakukan dengan berbagai topik berupa seminar, dosen tamu, simposium, dan lain sebagainya. Tetapi implementasi untuk melakukan terhadap jajaran akademisi, pimpinan di lingkungan kampus jarang dilakukan. Untuk itu perlu implementasi cek kesehatan faktor resiko penyakit tidak menular ini di kampus baik bagi jajaran pimpinan, dosendosen, mahasiswa. Tenaga yang telah dilatih dalam pencegahan faktor resiko ini dapat dimamfaatkan. Tahun 2019 ada 3 orang dari Unand yang telah dilatih, UNP Padang 2 orang, UNES 1 orang, Dinas Kesehatan Kota se Sumatera Barat, serta Organisasi Perangkat Daerah.

Pada sarana pelayanan kesehatan, tenaga kesehatan terlatih seperti Apoteker mempunyai tugas yang sangat dibutuhkan dalam keberhasilan mengatasi hipertensi. Salah satu tugas profesi kefarmasian yaitu memberikan informasi obat, memberikan konseling dan mendampingi pasien dalam mengatasi hipertensi sehari-hari khususnya dalam terapi penyakitnya secara rasional. Pemantauan terapi pada pasien hipertensi merupakan peran Apoteker. Apoteker dapat membantu pasien melaksanakan pola diet seperti yang dianjurkan ahli gizi, mencegah dan mengatasi komplikasi yang mungkin terjadi, menghindari dan mengendalikan akibat yang tidak diharapkan dari obat, memberikan saran penyesuaian diagnosis dan terapi obat yang harus dikonsumsi pasien bersama dengan tenaga medis.

Memberikan informasi kepada pasien tentang permasalahan yang berhubungan dengan kondisi terkini pasien dan pentingnya penatalaksanaan hipertensi dengan penyampaian yang dapat dipahami, sesuai dengan latar belakang pendidikan dan keadaan pasien. Cara penyampaian dapat dilakukan baik melalui diskusi maupun penjelasan lainnya. [21]

Menyampaikan dan mendiskusikan pada pasien tentang keuntungan melakukan terapi hipertensi menjadi sama pentingnya dengan mendiskusikan mengenai efek sampingnya. Jika pasien dapat mengerti adanya keuntungan potensial dari penggunaan obat hipertensi, maka tentu pasien akan cenderung mematuhi dan melakukan terapi tersebut. Pada saat Apoteker mendiskusikan efek sampingan obat, tentu mereka perlu pula membicarakan bagaimana pula mencegah serta menangani efek sampingannya agar pasien serius melaksakan kegiatan terapi obatnya. [21]

\section{KESIMPULAN}

Dari hasil penelitian ini dapat disimpulkan bahwa sebagian besar masyarakat mempunyai faktor resiko penyakit tidak menular tidak mengetahui batas normal cek kesehatan dan jarang mencek kesehatan secara teratur. Penyakit Tidak Menular di Gunung Padang sebagian besar adalah Hipertensi dan Kegemukan. Kadar gula darah terdeteksi sebagian besar normal, dan aktifitas fisik yang dilakukan diduga mempengaruhinya. Model pendekatan keluarga dimanapun berada dapat mencegah faktor resiko terhadap PTM

\section{DAFTAR PUSTAKa}

[1] Alan, Thomas, J.,1995, The Productin School: A System Analysis Approach to Education administration, Chichago University

[2] ndang-undang no.36 tahun 2009, tentang Kesehatan. Departemen Kesehatan

[3] Pedoman Pelaksanan Monitoring dan Evaluasi Program Indonesia Sehat dengan Pendekatan Keluarga (PIS-PK). Jakarta: Kementrian Kesehatan RI; 2017.

[4] Pedoman Penyelenggaraan Program Indonesia Sehat dengan Pendekatan Keluarga. Jakarta: Peraturan Menteri Kesehatan Republik Indonesia; 2016

[5] Permenkes RI Nomor 39 Tahun 2017 tentang Pedoman Penyelenggaraan Program Indonesia Sehat dengan Pendekatan Keluarga. Jakarta: Kementrian Kesehatan RI; 2017

[6] Pedoman Umum Program Indonesia Sehat dengan Pendekatan Keluarga Jakarta: SekretariatKementrian Kesehatan RI; 2017.

[7] Riset Kesehatan Dasar (2018). Kementrian Kesehatan Republik Indonesia

[8] Germas (2019). Modul Pelatihan Posbindu Institusi. Kementrian kesehatan Republik Indonesia.

[9] Infodatin Hipertensi. Jakarta: Kemenkes RI; 2013.

[10] Adib M. Cara Mudah Memahami dan Menghindari Hipertensi Jantung dan Stroke. Yogyakarta: Dianloka Pustaka Populer; 2009

[11]Laporan Tahunan Puskesmas Paninjawan. Paninjawan: Puskesmas Paninjawan; 2018

[12] Syafruddin H. Kebidanan Komunitas. Jakarta: EGC; 2009

[13] Trihono A. Manajemen Puskesmas. Jakarta: CV Agung Seto; 2005 
[14]Data Program Indonesia Sehat dengan Pendekatan Kelurga. Paninjawan: Puskesmas Paninjawan; 2019

[15] WHO. Hypertension 2018

[16] Kompas.com https://www.kompasiana.com /ajengp/5b0a9413dd0fa81f106e9a12/patientreminder-solusi-untuk-meningkatkanefisiensi-layanan-kesehatan)

[17]Feranita Utama.2017 Gambaran Penyakit Tidak Menular di Universitas Sriwijaya https://doi.org/10.23917/jurnal\%20kesehatan. v11i2.7593, diakses tanggal 19 Desember 2019.

[18] Nurul Ilmi Idrus(2017), Determinan Rutin Tekanan Darah Pada Pasien Hipertensi di Puskesmas Massenga Kabupaten Polewali Mandar, 2017

[19] Hasanusin (2018), Hubungan Tekanan Darah dengan masyarakat yang beratifitas fisik di Wilayah Tlugosuryo, Kota Malang

[20] Siswati, Shafira, at all (2019), PBL di Puskesmas Paninjauan Kabupaten Solok Sumatera Barat.

[21] Kowalski RE. Terapi Hipertensi. Makasar: PT Mizan Pustaka.; 2010

[22] Kementrian Kesehatan, (2019) Pelayanan Kefarmasian untuk pasien Hipertensi

\section{Biodata Penulis}

Sri Siswati, lahir di Bukittinggi, 8 Maret 1964, pendidikan terakhir Magister Kesehatan dari Universitas Indonesia, dosen Fakultas Kesehatan Masyarakat Unand Padang 